\title{
淡路島における兵庫県南部地震後の湧水・地下水の挙動
}

\author{
高村弘毅* ・ 河野 忠**

\section{Trend of Spring Water and Groundwater in the Awaji Island After the 1995 Hyogo-Nanbu Earthquake}

\author{
Hiroki TAKAMURA * Tadashi KONO**
}

要 約

1995年 1 月17日に生じた兵庫県南部地震は、淡路島に大きな被害を及ぼした。同時に、 淡路島には多くの湧水が存在するが、ある地域ではほとんどの井戸が涸渴するという現象 が発生した。また地震後、地下水・湧水の異常増水によって地方りや土地の冠水などの現 象も発生した。地震による地下水への様々な影響は、噴砂現象をはじめとして水量、水質 両面で、多様かつ広域に及んでいるものと思われる。そこで、兵庫県南部地震が淡路島の 湧水，地下水にいかなる影響を与え、またそれらにどのような変化が生じたかを明らかに し、その原因を究明するために、湧水・地下水の水量、および水質調査を実施した。

淡路島に扔ける湧水・地下水で、それぞれ湧出量の増加や減少、地下水位の上昇、低下 が観察された。これらは、断層の動きと地震動による地下水ポテンシャルの増加による地 下水位の一時的な上昇の結果によるものと考えられる。帯水層の亀裂が生じたような場合 には、水位が低下し枯渇する湧水もあった。断層付近の地震動の激しかった地域にある湧 水や地下水において無機溶存成分濃度の増加傾向が認められた。これは主に、高濃度の溶 存成分濃度を有する深層地下水の混入が原因であると考えられるが、地震動による各成分 の溶出量増加や地震動による熱の影響なども考えられる。

\section{Summary}

The 1995 Hyogo-Nanbu Earthquake, which attacked Japan on January 17, 1995, has brought severe damage to the Awaji Island. Indeed, most wells have dried up in a certain area of the island where there are many springs. The unusual swell of groundwater and

立证大学文学部地理学科

Department of Geography, Rissho University

日本文理大学

Nihonbunri University 
spring water has caused such phenomena as landslide and submergence of land after the earthquake. Apparently the earthquake has exerted various kinds of influence on both quantity and quality of the groundwater over a vast area including dust action. Quantitative and qualitative analyses of the spring water and groundwater were given in the Awaji Island to clarify the influence of the earthquake on both forms of water in the island and how the water has changed, and to seek the factors of the change.

Increase or decrease of spring water yield and upcoming or drawdown of groundwaterlevel are observed in the Awaji Island. These phenomena may have been caused by the change of groundwater potential in accordance with the action of fault and the earthquake shock. Some springs have dried up after experiencing drawdown probably because the aquifer has suffered fractures. Spring water and groundwater show a tendency to have increased their dissolved inorganic matter density around the faults where the earthquake shock was severe. It is suggested that this tendency turned up mainly because deep groundwater, which shows high density of the dissolved matters, has infiltrated into the spring water and groundwater and partly because the action of the earthquake shock enriched the dissolved matters and/or the heat produced by the shock has been influential.

\section{1 はじめに}

1995年 1 月17日に生じた兵庫県南部地震は、各 方面に多大なる影響を与え、また、ライフライン の断絶で改めて水の重要性が認識された。淡路島 には多くの湧水が存在し、島の人々はその生活用 水を地下水に頼っている。その淡路島北部の山間 地域でほとんどの井戸が涸渇するという現象が発 生したが、場所によっては地震後、地下水・湧水 の異常増水によって地沪りや土地の冠水などの現 象も発生した。その他、今回の調査では確認され ていない地域においても様々な湧水、地下水への 影響が生じていることが現地において報告されて いることから、地震による地下水への影響は、噴 砂現象をはじめとして水量、水質雨面で、多様か つ広域に及んでいるものと思われる。このことか ら、防災用、非常用として全国的に設置されてい る水井戸の安全性についても再検討しておく必要 がある。そこで、兵庫県南部地震が淡路島の湧水、 地下水にいかなる影響を与え、またそれらにどの ような変化が生じたかを明らかにし、その原因を 究明するために、湧水・地下水の水量、および水 質調査を実施した。

被災地の状況に対する配慮から現地の調査に限 界があり、資料不足の点もあるが、緊急のニュー ス性と今後の危機予見の重要性に鑑み報告するこ
ととした。

\section{2 研究地域の概要}

（1）地質と地形

淡路島は南西方向に細長い形をし、断層によっ て区切られた直線的な海岸を持つ島である。淡路 島北端から南西方向に海抜200～300m ほどの春梁 山脈がのびている。中央部には海抜 $448 \mathrm{~m}$ の先山 があり、その周辺部には扇状地が発達しており、 古くから多くの湧水が分布する地域でもある。最 南部には海抜 $608 \mathrm{~m}$ の諭鶴羽山を中心とした諭鶴 羽山地が東西方向にのびている。市原ほか(1991) や兵庫県 (1995) から作成した淡路島の地質の概要 を図 1 に示す。淡路島の北部では主に花崗岩類、 第三紀層が卓越しており、その上をマサ土が覆つ ている。また南部は和泉層群、沖積層によって占 められている。

\section{（2）地震により生じた断層}

淡路島には、野島断層をはじめとして楠本断層、 浅野断層などの多くの断層が存在する。これらは 北東から南西に向けてのびて㧍り、直交するよう に育波断層や志筑断層がのびている。

太田・堀野(1995)によると、兵庫県南部地震に よって活動したと考えられる野島断層は、淡路島 


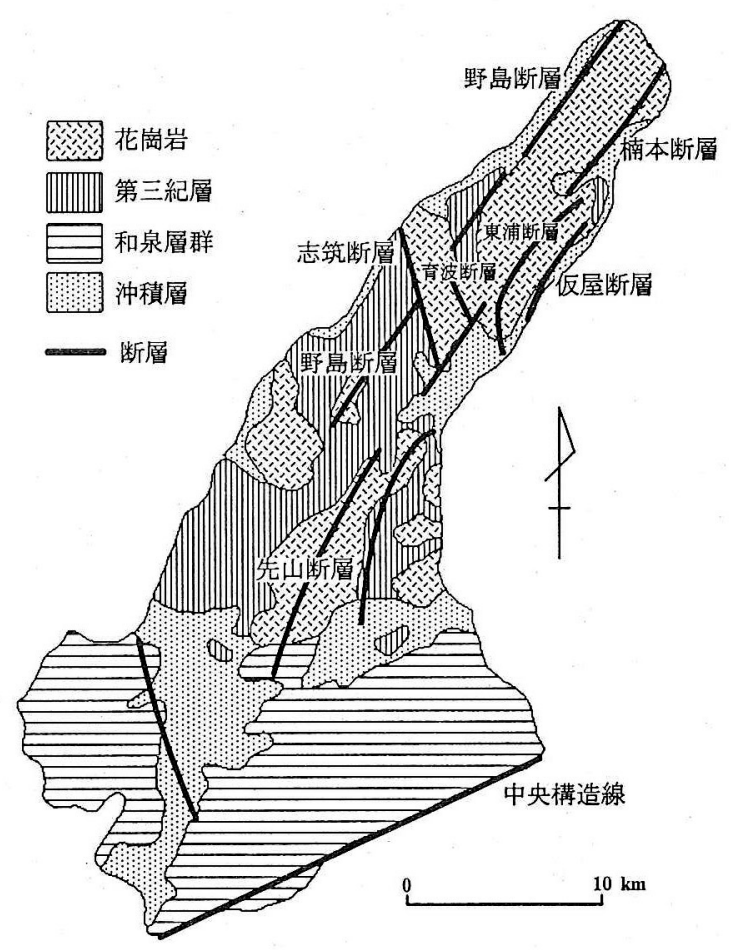

図-1 淡路島の地質概要

北端にある江崎灯台から北淡町中心部の富島ま で、9 kmにわたって出現した。ほぼ一直線に並 んでいるが、ところによっては雁行割れ目を呈す るところもある。断層は、すべて右横ずれで、最 大の横ずれ変位量が $170 \mathrm{~cm}$ に達し、縦ずれは一般 に南東上がりで、最大縦ずれ変位量は $130 \mathrm{~cm} に な$ る。

\section{3 研究方法}

調查は、1995年 3 月18日〜23日の期間実施した。 調查対象は、湧水と井戸に絞った。調査方法は、 湧水・地下水についての聞き取り調查、湧水の湧 出量、地下水位、および水質調査である。聞き取 り調査は、地震前後で湧水と井戸水の水量や水質 の変化をなるべく詳しく、聞き取るように努め、 量的な推定ができるように心がけた。調査地点の 選定には、波毛(1986)を参考にした。

現地での観測項目は、湧出量、地下水位、水温、 電気伝導度 (以下 $\mathrm{EC}$ ) 、 $\mathrm{pH} 、 \mathrm{RpH}$ である。湧出量 の測定は、三協精密製微流速計 SV-101型を用い、 その流速と断面積から湧出量を求めた。また、パ
イプ等から湧出している場合はビニール袋を用い た。水温と EC は、TOA 電波製 CM-11P 使用し、 水銀温度計を用いて水温を補正した。なお、 $\mathrm{EC}$ は $25^{\circ} \mathrm{C}$ の值に補正してある。 $\mathrm{pH} 、 \mathrm{RpH}$ は、比色 法を用いた。 RpHは、サンプルを試験管にとり 5 分間攪拌した後、測定した。

水質分析は、検水は湧出地点で250ccのポリビ ンに採水、水冷、実験室に持ち帰り実施した。水 質分析項目は、主要無機成分の $\mathrm{Na}^{+} 、 \mathrm{~K}^{+} 、 \mathrm{Ca}^{2+}$ 、 $\mathrm{Mg}^{2+} 、 \mathrm{NH}_{4}{ }^{+} 、 \mathrm{SO}_{4}{ }^{2-} 、 \mathrm{Cl}^{-} 、 \mathrm{HCO}_{3}{ }^{-} 、 \mathrm{NO}_{3}{ }^{-} 、 \mathrm{NO}_{2}{ }^{-}$、 $\mathrm{SiO}_{2}$ である。分析には、日本文理大学環境科学研 究所のダイオネクス社製イオンクロマトグラフ DXAQ-1211を用いた。サンプル水は、富士フィ ルム製 $0.2 \mu \mathrm{m}$ のディスクカプセルにより滤過を 行い、イオンクロマトグラフに供した。また $\mathrm{HCO}_{3}$-は、JIS-KO101に基づき、 $\mathrm{pH} 4.8$ アルカリ 度として定量した。 $\mathrm{SiO}_{2}$ は、分光光度計を用いて、 モリブデン黄法により分析した。

\section{4 結果と考察}

（1）湧水の湧出量と地下水位の変化

図 2 に地震後における湧出量と地下水位の変化 を示す。この図によると北淡町仁井地区を除き、 断層の西側に位置する湧水、井戸の湧出量・地下 水位が上昇する傾向が認められる。多くの湧水で、 地震後の湧出量増加が観察され、3月の時点では 多少の減少傾向は見られるものの、普段の $2 \sim 5$ 倍程度の湧出量を示していた。逆に、断層の東側 や山間部、淡路島南部の一部で湧出量の減少や地 下水位の低下がみられた。また、湧出量、水位変 化の不明な観測地点でも、何らかの変化が生じて いると考えられる。佐藤・高橋 (1995) の地震直後 の湧水調査によると、野島、楠本断層に沿って多 数の湧水が生じたことが報告されている。また、 同じく地震直後（1月20日～23日）に湧水、河川 の湧出量、流量調查を実施した田中ほか(1995)の 報告によると、淡路島全域にわたり、ほとんどの 湧水、河川で水量が増加したことが確認された。

淡路島北部北淡町仁井地区のほとんどの井戸は 涸渇状態であった。この地域は、野島断層と楠本 断層に挟まれた山間の丘陵地に位置する地域であ る。仁井地区では、地震前後に急激な水位上昇が 見られ、その後 2 日〜 10日前後で水位が低下して 


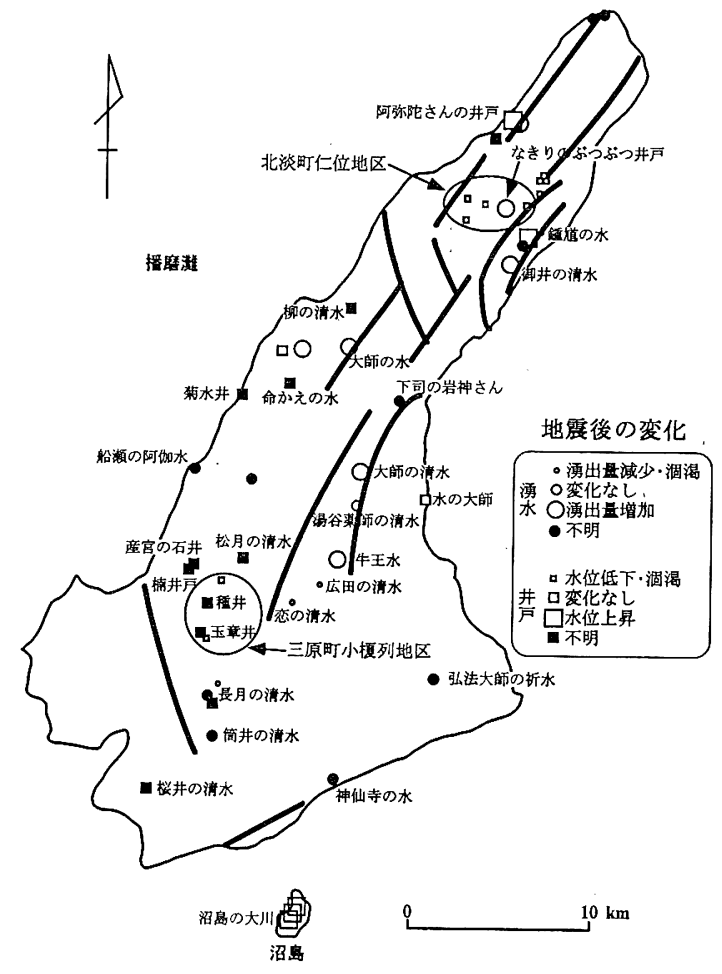

図一2 兵庫県南部地震後の湧水 · 地下水の変化

涸渴した。ほとんどの井戸が枯渇した中で、なき りのぶつぶつ井戸と呼ばれる井戸付近の水田で、 地割れと噴砂現象が多数みられる。井戸自体も地 震によりねじ切られた状態になっており、水位上 昇により、付近から地下水が噴出していた。

淡路島南部の井戸は、地下水位の異常現象はあ まりみられなかったが、玉章井のある三原町小榎 列地区の井戸では、地震直後に水位の上昇と白い 濁りが観察され、その後水位は平年より低下した。 また、この地区には枯渴した井戸が多少みられた。

地下水位が上昇したまま低下しない井戸水は、 淡路島北部の断層付近から新たな湧水が出現した 付近の井戸と、淡路島南部の沼島にある井戸でみ られた。

今回の地震における断層は、右横ずれであり、 かつ東側が上昇していることから、この現象のモ デルは図 3 のように考えられる。特にこの現象が 典型的にみられたところが阿弥陀さんの井戸であ る。地震により地云りを生じ、帯水層を切る形で 新たな湧水が生じ、その下流に当たる井戸の水位

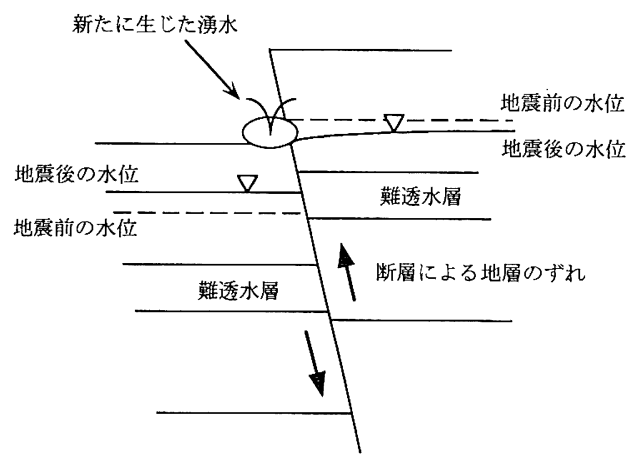

図ー3 野島断層付近の地下水の挙動

が地表面と同じ高さになっていた。

淡路島の名水の一つ、鍾馗の水は調査時点で涸 渴していたが、地震直後は湧出量の増加が見られ、 周辺の湧水でも湧出量の増加現象が観察された。

しかし、鍾㐤の水は、花崗岩の割れ目から湧出す る裂か水と考えられ、地震動による花崗岩の亀裂 が原因で枯渴したものと考えられる。

山間の狭隘な帯水層の地下水は、岩盤や難透水 層中に亀裂が生じた場合、地震動による一時的な ポテンシャルの増加により水位は上昇するが、そ の後、断層や亀裂へ地下水が落ち込むとともに水 位が低下し、涸渴すると考えられる。

それに対して、海岸部や扇状地などの広域な带 水層中を流動する地下水はごく一部に打いて水位 低下がみられたものの、多くの井戸において、一 時的なポテンシャルの増加に伴う水位の上昇が生 じた。また、海岸付近にあり、感潮域の地下水帯 にある井戸 (淡路島南部に位置する沼島の井戸群 など)は、地震動による一時的な水位の上昇後も、 調査時点では水位低下が生じなかった。

聞き取り調査から地震後の変化を考慮に入れ、 湧出量・水位の変化を示すと図 4 のようになる。 大略 5 つのパターンに分類される。調査時点で地 下水位が上昇したまま下がらないパターン Aに属 する湧水・井戸は、いずれパターン Bになるもの と考えられる。また、パターン B ・ C の湧出量・ 水位上昇のピークに達する時間は、場所によって 異なり、0〜10日位であった。震源に近い北淡町 付近のピーク時間は比較的短く0〜 3 日程度で あった。 


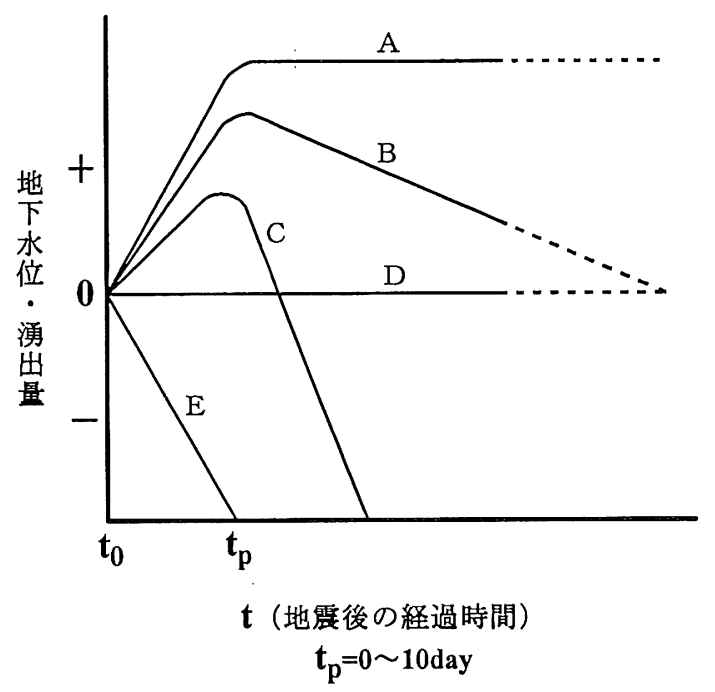

図一４地震後の湧出量・地下水位の変化パターン
（2）淡路島の湧水 - 地下水の水文化学的特徵 今回の水質分析結果と、地震前の水質データと して波毛・西村 (1994)が1994年 8 月の水質データ を発表しているので、これをあわせて表 1 に示す。

淡路島の水質の概要を知るために、トリリニア ダイヤグラム(図 5 )を作成した。これによると淡 路島の湧水、地下水は、花崗岩の卓越する地域で は典型的な $\mathrm{Ca}-\mathrm{HCO}_{3}$ 型の水質を示している。と ころが海岸付近に位置する地下水は海水の影響を 受けるために、 $\mathrm{Na}-\mathrm{Cl}$ 型の水質を示している。ま た、淡路島南部地域で扇状地の沖積層や和泉層群 に位置する湧水・地下水のなかには神仙寺の水の ような特殊な水質を示すものや、 $\mathrm{NO}_{3}{ }^{-}$濃度が高 く人為污染の進んでいる湧水、地下水も認められ る。淡路島の湧水、地下水の基本的な性質は、そ の地質によって支配されていると考えてよいであ ろう。

\section{（3）地震前後の水質変化}

表 1 の地震前後の水質データは分析者の異なる 水質データで、地震前後各 1 回のみのデータであ ることから、このデータから結論的なことを述べ ることは無理であるが、ある程度の推定、傾向の 把握は可能であろう。さらに、1994年夏季は記録 的な渴水で、水量、水質に多大なる影響を与えた

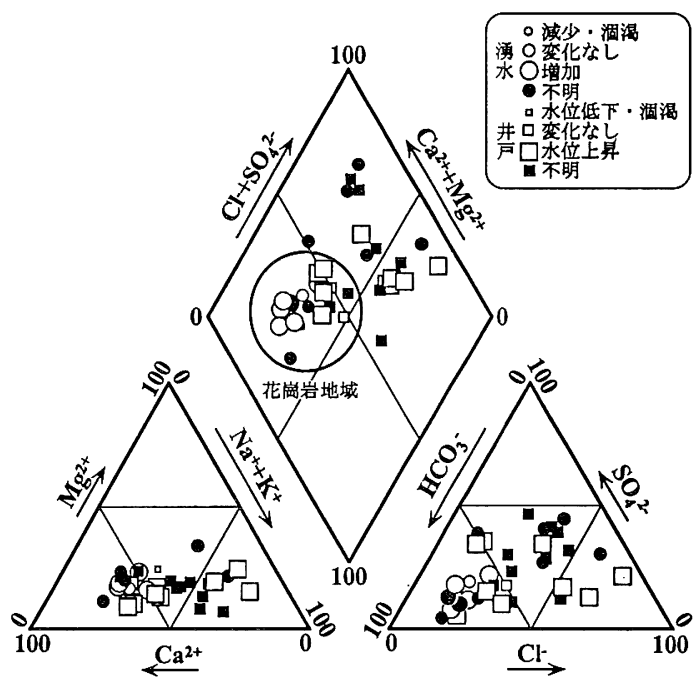

図－5 湧水・地下水の水質のトリリニアダイヤグ ラム

ものと考えられる。以後、これらを考慮して述心゙ ることとする。

表 1 から明らかなように、地震後の淡路島北部 から中部にかけての湧水・地下水の水質は、ほと んどの成分で濃度の増加傾向を示している。北部 の湧水・地下水では $\mathrm{Na}^{+} 、 \mathrm{Ca}^{2+} 、 \mathrm{SO}_{4}{ }^{2-}$ 、 $\mathrm{HCO}_{3}{ }^{-}$濃度が増加し、他の成分は減少した。一 方南部の湧水・地下水は、濃度が一定もしくは、 低下寸る傾向がみられた。南部の水質は、 $\mathrm{HCO}_{3}{ }^{-}$と $\mathrm{NO}_{3}{ }^{-}$で濃度の増加がみられた。北部・ 中部と南部で水質変化に一定の傾向がみられるこ とから、地震前後のデータの信憑性は、かなり高 いものと考えてよいであろう。

基本的に地震の震源地に近く、地款変動の激し い花崗岩と第三紀層の卓越する地域での溶存成分 濃度の増加が顕著であり、比較的震源地から離れ た地域や和泉層群や沖積地にある観測地点での水 質変化が少ないことがわかる。佐藤・高橋 (1995) も淡路島北部において同様の結果を得ており、こ の原因について、淡路島の湧水は、 $\mathrm{NO}_{3}{ }^{-}$濃度が 低く、 $\mathrm{F}^{-}$の濃度が高い (最大 $\left.3 \mathrm{mg} / \mathrm{l}\right)$ ことから、 花崗岩と第三紀層の浅い地下水が流出した可能性 が高いことを指摘している。また $\mathrm{HCO}_{3}{ }^{-}$濃度が 地震前よりも高くなっていることから、深層地下 水の混入がその原因ではないか、と述べている。 
表 -1 淡路島涌水・地下水観測結果

\begin{tabular}{|c|c|c|c|c|c|c|c|c|c|c|c|c|c|c|c|c|c|c|c|c|c|c|}
\hline & 地点名 & 観测日 & 種類 & \multicolumn{2}{|c|}{$\begin{array}{l}\text { 涌出量 } \\
\text { ec t/day }\end{array}$} & \multirow{2}{*}{$\begin{array}{c}\text { Tw } \\
{ }^{\circ} \mathrm{C} \\
14.8\end{array}$} & $\begin{array}{c}\text { E.C. } \\
\mu \mathrm{S} / \mathrm{cm}\end{array}$ & \multicolumn{2}{|c|}{$\mathrm{pH} \mathrm{RpH}$} & \multirow[t]{2}{*}{$\begin{array}{l}\mathrm{Na}^{+} \\
\mathrm{mg} / \mathrm{l}\end{array}$} & \multirow{2}{*}{$\begin{array}{r}\begin{array}{c}\mathrm{K}^{+} \\
\mathrm{mg} / 1\end{array} \\
2.7\end{array}$} & \multirow{2}{*}{$\begin{array}{c}\begin{array}{l}\mathrm{Ca}^{2+} \\
\mathrm{mg} / 1\end{array} \\
43.6\end{array}$} & \multirow{2}{*}{$\begin{array}{c}\begin{array}{l}\mathrm{Mg}^{2+} \\
\mathrm{mg} / 1\end{array} \\
12.1\end{array}$} & \multirow{2}{*}{$\begin{array}{r}\begin{array}{r}\mathrm{NH}_{4}^{+} \\
\mathrm{mg} / \mathrm{l}\end{array} \\
0.0\end{array}$} & \multirow{2}{*}{$\begin{array}{c}\mathrm{SO}_{4}{ }^{2-} \\
\mathrm{mg} / \mathrm{l}\end{array}$} & \multirow{2}{*}{$\frac{\begin{array}{c}\mathrm{Cl}^{-} \\
\mathrm{mg} / \mathrm{l}\end{array}}{30.5}$} & $\begin{array}{c}\mathrm{HCO}_{3}{ }^{-} \\
\mathrm{mg} / 1\end{array}$ & $\begin{array}{l}\mathrm{NO}_{3} \\
\mathrm{mg} / 1 \\
\end{array}$ & $\begin{array}{l}\mathrm{NO}_{2}^{-} \\
\mathrm{mg} / \mathrm{l}\end{array}$ & $\begin{array}{l}\mathrm{PO}_{4}{ }^{3-} \\
\mathrm{mg} / 1\end{array}$ & $\begin{array}{c}\mathrm{F}^{-} \\
\mathrm{mg} / \mathrm{l}\end{array}$ & $\begin{array}{l}\mathrm{SiO}_{2} \\
\mathrm{mg} / 1\end{array}$ \\
\hline & 1 阿弥陀さん湧水 & $95 / 03 / 21$ & $\mathrm{~S}$ & 2.00 & 172.8 & & 412 & 7.5 & 8.0 & & & & & & & & & 0.0 & 0.0 & 0.0 & 1.1 & 55.4 \\
\hline & 2 阿弥陀さんの井戸 & $95 / 03 / 21$ & W & & & 13.8 & 291 & 5.6 & 7.6 & 22.7 & 1.3 & 25.6 & 5.3 & 0.0 & 44.9 & 32.8 & 43.7 & 3.0 & 0.0 & 0.0 & .3 & 41.2 \\
\hline & 3 真泉寺井戸 & $95 / 03 / 21$ & W & & & 14.4 & 569 & 7.1 & 7.9 & 59.7 & 2.7 & 32.2 & 4.6 & 0.0 & 73.0 & 77.3 & & 15.2 & 0.0 & 0.0 & .5 & 37.0 \\
\hline & 4 猪坂㓮正宅井戸 & $95 / 03 / 19$ & W & & & 14.7 & 575 & 6.6 & 8.1 & 43.8 & 7.0 & 51.9 & 17.6 & 0.1 & 29.5 & 42.6 & & 1.5 & 0.2 & 0.0 & .5 & 37.8 \\
\hline & 5 鍾道の水(2) & $95 / 03 / 19$ & $\mathrm{~W}$ & & & 16.2 & 268 & 7.3 & 7.9 & 16.2 & 1.7 & 31.6 & 5.9 & 0.0 & 8.0 & 19.7 & & 0.0 & 0.0 & 0.0 & .5 & 36.6 \\
\hline & 6 鍾惪の水(3) & $95 / 03 / 19$ & $\mathrm{~S}$ & 9.44 & 815.4 & 15.4 & 277 & 7.2 & 7.8 & 20.3 & 1.8 & 29.2 & 5.7 & 0.0 & 16.7 & 23.7 & & 1.3 & 0.0 & 0.0 & .4 & 28.4 \\
\hline & 7 御井の清水 & $5 / 03 / 19$ & $S$ & 0.14 & 12.1 & 14.1 & 262 & 7.5 & 7.8 & 18.3 & 1.6 & 26.3 & 5.3 & 0.0 & 25.2 & 19.7 & 78.1 & 4.0 & 0.0 & 0.0 & 0.2 & 17.7 \\
\hline$\star$ & 御井の清水 & $94 / 08 / 19$ & $S$ & & & 15.7 & 264 & 7.1 & & 17.5 & 2.8 & 23.2 & 5.3 & & 22.4 & 21.9 & 67.0 & 5.0 & & & & 18.9 \\
\hline & 8 橮の清水 & $/ 03 / 18$ & W & & & 11.7 & 370 & 7.1 & 7.8 & 28.8 & 3.6 & 26.0 & 7.6 & 2.7 & 30.5 & 33.3 & 110.3 & 0.8 & 0.2 & 0.4 & 0.5 & 20.6 \\
\hline & 9 大師の水 & $5 / 03 / 18$ & $S$ & 0.72 & 62.6 & 17.4 & 343 & 7.5 & 8.0 & 23.0 & 1.5 & 42.2 & 6.0 & 0.1 & 12.5 & 21.9 & 154.7 & 0.0 & 0.0 & 0.0 & 0.4 & 27.3 \\
\hline$\star$ & 大師の水 & //08/19 & $\mathrm{S}$ & & & 18.2 & 344 & 7.5 & & 21.7 & 2.6 & 39.2 & 5.1 & & 6.5 & 23.4 & 128.0 & 0.2 & & & & 27.8 \\
\hline & 丁道涌水 & $/ 03 / 21$ & $\mathrm{~S}$ & 1.00 & 86.4 & 17.1 & 394 & 7.4 & 8.0 & 27.7 & 1.4 & 46.7 & 6.4 & 0.1 & 18.2 & 25.7 & 166.0 & 0.0 & 0.0 & 0.0 & 0.7 & 37.6 \\
\hline & 棈車井戸 & $5 / 03 / 20$ & W & & & 11.1 & 592 & 6.3 & 7.8 & 61.5 & 1.3 & 26.7 & 10.4 & 0.0 & 71.7 & 75.7 & 96.9 & 1.8 & 0.0 & 0.0 & 0.5 & 45.8 \\
\hline & 12 智禅寺横井戸 & $5 / 03 / 20$ & W & & & 14.0 & 458 & 6.3 & 7.9 & 48.0 & 1.4 & 29.7 & 10.4 & 0.0 & 25.0 & 56.6 & 136.2 & 0.5 & 0.0 & 0.0 & 0.3 & 41.6 \\
\hline & 13 命力 & $5 / 03 / 20$ & W & & & 10.5 & 189 & 6.7 & 7.5 & 25.3 & 0.4 & 8.9 & 1.5 & 0.0 & 22.4 & 13.8 & 38.6 & 11.7 & 0.0 & 0.0 & 0.2 & 35.8 \\
\hline & 14 菊水井 & $/ 03 / 20$ & W & & & 11.0 & 608 & 7.1 & 7.6 & 57.5 & 10.2 & 32.3 & 8.4 & 0.0 & 28.2 & 87.1 & 92.8 & 16.1 & 0.0 & 5.6 & 0.2 & 23.5 \\
\hline & の䦥伽水 & $/ 03 / 20$ & $\mathrm{~W}$ & & & 13.1 & 341 & 5.9 & 7.7 & 28.5 & 1.3 & 13.4 & 12.3 & 0.0 & 37.6 & 40.7 & 53.0 & 7.6 & 0.0 & 0.0 & 0.1 & 26.3 \\
\hline$\star$ & 船瀬の閣伽水 & //08/19 & $\mathrm{W}$ & & & 23.9 & 360 & 6.0 & & 31.0 & 1.8 & 14.4 & 12.3 & & 40.0 & 51.4 & 49 & 8.3 & & & & 29.2 \\
\hline & 岩神さん & $3 / 22$ & $\mathrm{~s}$ & 0.10 & 8.6 & 13.6 & 243 & 7.5 & 8.0 & 20.8 & 1.3 & 25.3 & 4.3 & 0.0 & 5.6 & 12.9 & 110 & 1.0 & 0.0 & 0.0 & 1.4 & 23.1 \\
\hline & 17 大師 & $3 / 21$ & $\mathrm{~S}$ & 0.71 & 61.3 & 15.7 & 361 & 7.3 & 8.0 & 20.4 & $1: 0$ & 43.9 & 8.6 & 0.0 & 23.0 & 16.8 & 152 & 2.3 & 0.0 & 0.0 & 0.5 & 17.7 \\
\hline$\star$ & 清水 & /08/19 & $\mathrm{s}$ & & & 16.5 & 328 & 7.4 & & 18.8 & 1.6 & 39.6 & 9.7 & & 21.4 & 19.1 & 132 & 2.5 & & & & 19.2 \\
\hline & 師の清水 & $3 / 21$ & $\mathrm{~s}$ & 5.05 & 436.7 & 15.3 & 196 & 7.8 & 8.0 & 12.3 & 1.0 & 21.8 & 3.5 & 0.0 & 16.9 & 11.1 & 65 & 4.2 & 0.0 & 0.0 & 0.3 & 16.6 \\
\hline$\star$ & 師の清水 & $08 / 19$ & $\mathrm{~s}$ & & & 15.8 & 189 & 7.8 & & 10.6 & 1.6 & 19.2 & 3.4 & & 10.6 & 13.4 & 0 & 6.1 & & & & 16.9 \\
\hline & 19 水 $\sigma$ & & W & & & 12.4 & 328 & 7.1 & 7.8 & 26.3 & 1.0 & 28.6 & 6.2 & 0.0 & 26.9 & 33.7 & 8 & 2.3 & 0.0 & 0.0 & 0.3 & 20.5 \\
\hline 夫 & 水の & $08 / 19$ & W & & & 19.5 & 315 & 7.7 & & 23.2 & 2.3 & 29.2 & 5.8 & & 15.9 & 28. & 0 & 1.0 & & & & 18.7 \\
\hline & 20 牛王水 & & $\mathrm{S}$ & 3.77 & 325.7 & 15.4 & 249 & 7.4 & 7.9 & 13.1 & 1.0 & 30.7 & 5.2 & 0.0 & 20.4 & 11.4 & 2 & 1.7 & 0.0 & 0.0 & 0.3 & 13.9 \\
\hline 夫 & 牛王水 & $8 / 19$ & $\mathrm{~S}$ & & & 15.0 & 246 & 7.0 & & 12.2 & 1.6 & 27.6 & 5.5 & & 15.2 & 14.1 & 0 & 3.2 & & & & 15.4 \\
\hline & 21 松月 & & W & & & 13.6 & 324 & 6.2 & 7.6 & 28. & 0.7 & 21.2 & 5.7 & 0.0 & 59.2 & 22.2 & & 33.3 & 0.0 & 0.0 & 0.2 & 37.4 \\
\hline & 22 玉章 & & W & & & 11.9 & 455 & 6.3 & 7.5 & 23. & 3.8 & 41.2 & 11.3 & 0.0 & 58.4 & 40. & & 56.1 & 0.0 & 0.0 & 0.0 & 19.3 \\
\hline$\star$ & 玉章 & & W & & & 22.7 & 575 & 5.8 & & 26 & 7.6 & 50.0 & 16.0 & & 87.8 & 49. & & 17.4 & & & & 24.8 \\
\hline & 23 長月の清水 & & $\mathrm{s}$ & 0.00 & 0.0 & 10.4 & & 6.0 & 7.3 & 19 & 5.7 & 52.2 & & 0.0 & 56.6 & 35 & & & & 0.0 & 0.0 & 12.2 \\
\hline & 4 長月庵の井戸 & $03 / 22$ & W & & & 11.6 & & 6.2 & 7.6 & 20.3 & & & & 0.0 & 67.0 & 41 & 7 & & 0 & 0.0 & 0.5 & 12.3 \\
\hline & 25 筒井の清水 & & S & 0.25 & 21.3 & 13.7 & 95 & 5.9 & 7.9 & 21. & 4.0 & 0.0 & 12.2 & 0.0 & 61.0 & & & & 0.0 & 0.0 & 0.0 & 17.6 \\
\hline$\star$ & 筒井の清水 & $08 / 19$ & $\mathrm{~S}$ & & & 20.3 & 68 & 5.7 & & 23 & 6.8 & 3.6 & 14.8 & & 82.0 & 46.4 & 0 & 7.2 & & & & 19.9 \\
\hline & 26 桜井の清水 & $5 / 03 / 22$ & W & & & 14.9 & 395 & 6.3 & 7.7 & 31.0 & 6 & 28.3 & 7.8 & 0.0 & 36.8 & 33.4 & & 31.7 & .0 & 1.1 & 0.3 & 25.2 \\
\hline & 27 弘法大師の新水 & $/ 03 / 22$ & $\mathrm{~S}$ & 0.10 & 8.6 & 6.5 & 79 & 6.1 & 6.3 & 8.1 & 0.7 & 2.3 & 1.6 & 0.0 & 7.7 & 10.5 & 7 & 7.4 & 0.0 & 0.0 & .0 & 11.8 \\
\hline & 28 神仙寺の水 & $/ 03 / 22$ & S & 0.05 & 4.3 & 13.6 & 419 & 7.9 & 8.1 & 19.1 & 8 & 59.9 & 6.1 & 0.0 & 77.6 & 15.7 & 122.8 & 5.4 & 0.0 & 0.0 & 0.4 & 15.3 \\
\hline$\star$ & 柛仙寺の水 & $/ 08 / 19$ & s & & & 16.9 & 543 & 7.8 & & 19.5 & 1.7 & 62.8 & 7.2 & & 83.9 & 19.5 & 121.0 & 5.1 & & & & 16.3 \\
\hline & 29 沼島の大川 & $03 / 22$ & W & & & 14.6 & 252 & 6.0 & 7.5 & 27. & 1.0 & 5.6 & 5.9 & 0.0 & 12.6 & 42.9 & & 1.1 & 0.0 & 0.0 & 0.1 & 20.3 \\
\hline$\star$ & 沼島の大川 & /08/19 & W & & & 18.4 & 237 & 5.4 & & 28.7 & 1.4 & 4.0 & 5.1 & & 6.0 & 53.5 & & 1.4 & & & & 22.2 \\
\hline & 30 沿島八幡井戸 & $03 / 22$ & W & & & 14.5 & 549 & 6.2 & 7.3 & 61.2 & 3.5 & 11.3 & 7.1 & 0.0 & 39.8 & 95.6 & 17 & 5.7 & 0.0 & 1.4 & 0.0 & 17.4 \\
\hline & 31 堂の壶 & $03 / 22$ & W & & & 15.5 & 770 & 7.5 & 8.3 & 62.9 & 15.4 & 76.7 & 10.6 & 0.0 & 49.1 & 67.7 & & 26.4 & 0.0 & 6.6 & 0.0 & 38.7 \\
\hline & 32 泉の川 & $03 / 22$ & $\mathrm{w}$ & & & & 692 & 6.6 & 7.9 & 74,6 . & 12.1 & 31.3 & 14.8 & 0.0 & 44.9 & 103.0 & & 51.2 & 0.0 & 5.6 & & 32.5 \\
\hline & 33 長崎井戸 & $03 / 22$ & W & & & & 366 & 7.3 & 8.0 & 24.9 & 1.2 & 42.8 & 4.5 & 0.0 & 60.7 & 17.9 & & 2 & 0 & 1.7 & 0.2 & 12.2 \\
\hline & 34 浜井戸 & & W & & & & & 7.5 & 8.0 & 26. & 8 & 48 & 4 & 0.0 & 62.1 & 17 & & 1.3 & & 0.0 & 0.3 & 12.4 \\
\hline & 35 小半川 & $95 / 03 / 22$ & W & & & 13.5 & 449 & 7.3 & 8.0 & 35.3 & 1.7 & 43.3 & 8.7 & 0.0 & 23.4 & 51.8 & 139.6 & 2.0 & 0.0 & 0.0 & 0.3 & 25.2 \\
\hline
\end{tabular}

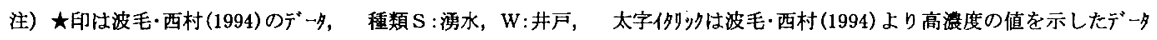

今回の調査データでは、 $\mathrm{F}^{-}$濃度の高い湧水はほ とんど認められないが、 $\mathrm{HCO}_{3}{ }^{-}$濃度については、 地震後佐藤らと同様に高い值を示している。また、 角皆・脇田 (1995) が行った神戸でのミネラル ウォーターを利用した地震前後の水質変化の研究 によると、深層地下水の上昇が原因と考えられる $\mathrm{Cl}^{-} 、 \mathrm{SO}_{4}{ }^{2-}$ 濃度の増加が報告されている。以上 のことを考慮すると、今回筆者ら得た水質変化に ついても深層地下水の上昇がその一因として考元 るべきであろう。

ところで、吉岡 (1988) は、地層の風化による水 質の変化を指摘し、それが地滑りと非常によい関 係であることを見いだした。特に、地滑り地にお いて、 $\mathrm{HCO}_{3}$-濃度が上昇する傾向にあるという 指摘から、淡路島に扔ける水質の変化も断層の動
きを地滑り面と同様に考えると、地震動により地 下水が帯水層中でもまれた結果、無機成分の溶脱 が一気に進み、無機溶存成分濃度が上昇したとも 考えられる。トリリニアダイヤグラム上で地震前 後の水質変化をプロットすると (図 6 )、淡路島東 部の海岸沿いにある水の大師と玉章井を除き、総 て $\mathrm{HCO}_{3}{ }^{-}$の割合が増加する方向に変化している ことがわかる。このことからも、地震が地下水の 水質変化を生じさせたといえるであろう。

他にも、石井ほか(1995) は神戸市での深層地下 水の全炭酸濃度の増加原因として、断層に沿って 深部の高温水が上昇し、浅層地下水に混入したと 考えている。深層地下水の混入かどうかは別にし ても、直接的、間接的に断層熱が浅層地下水の水 温を一時的に上昇させたとすれば、無機成分の溶 


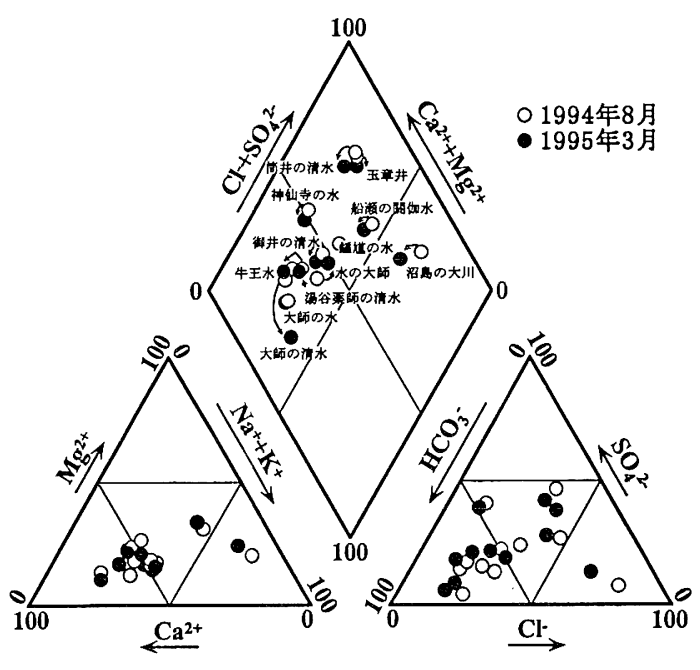

図－6 地震前後の水質の変化

脱促進も一因であると考えなければならない。特 に、今回の水質の変化データでは、淡路島北部の 断層付近の湧水が顕著であることから、野島断層 などの変異の激しい断層がその水質変化を生じさ せたことが原因していると推定される。この仮定 が成立するならば、断層によって生じた亀裂から の深層地下水の上昇、混入、及び断層熱による化 学的変化が水質の変化の原因であると考えた方が 妥当となる。

古武家ほか(1995) は地震後の兵庫県東部を流れ る猪名川水系の河川水、湧水中の重金属濃度が上 昇したことを報告している。その増加原因として 損壊家屋・ビルの解体による粉塵の飛散などとと もに、湧水や自噴井からの溢水を考えている。い ずれにせよ、深層の地下水が浅層地下水へ混入し、 水質に何らかの影響を与えたことは間違いないで あろう。

\section{5 おわりに}

淡路島における湧水・地下水で、それぞれ湧出 量の増加や減少、地下水位の上昇、低下が観察さ れた。これらは、断層の動きと地震動による地下 水ポテンシャルの上昇による地下水位の一時的な 上昇の結果によるものと考えられる。同時に、带 水層に亀裂が生じた場合などに水位が低下し、枯 渴する場合もあった。

水質面からも地下水に変化が生じており、断層
付近の地震動の激しい地域にある湧水や地下水の 無機溶存成分濃度の増加傾向が認められた。これ は主に、高濃度の溶存成分濃度を有する深層地下 水からの混入が原因であると考えられるが、地震 動そのものや地震動による熱の影響なども考えら れる。

本論文は、1995年日本地理学会秋季大会 (岡山大 学)で発表したものを加筆修正したものである。

\section{謝辞}

本研究は、日本文理大学環境科学研究所研究費 の一部、ならびに立正大学の研究費の一部を使用 し、実施した。水質分析にあたっては、日本文理 大学環境科学研究所村谷俊雄先生に実験室および イオンクロマトグラフを快く使用させていただい た。ここに記して深く感謝の意を表する次第であ る。

最後に、今回の地震で、お亡くなりになられた 多くの方々のご冥福を打祈りする次第である。

\section{参考文献}

石井武政・風早康平・安原正也・佐藤 努 (1995)：神 戸市周辺の地下水と兵庫県南部地震、日本水文科学 会学術大会講演予稿集、42 45.

市原 実 - 駿河 進 - 佐藤光男 (1991) : 大阪 - 奈良地 域の地質断面図、アーバンクボ夕、No.30.

太田陽子・堀野正勝 (1995)：1995年兵庫県南部地震の

際に出現した野島地震断層と被害状況. 地学雑誌、

Vol.104. No. 1、143 153.

角皆 潤 - 脇田 宏 (1995)：1995年兵庫県南部地震前 の地下水の化学組成の変化、月刊地球、号外No.13、 190 193 .

古武家善成・山本 淳 - 駒井幸雄・梅木 諭 (1995)：

兵庫県南部地震に伴う陸水、雨水中重金属濃度の変

化、日本陸水学会講演要旨集 (名古屋)、p.113.

佐藤 努・高橋 誠 (1995)：淡路島で生じた湧水一 1995年兵庫県南部地震に伴う地下水変化一、日本水 文科学会学術大会講演予稿集、 $46 \sim 47$.

田中和広・千木良雅弘・宮川公雄・馬原保典・長谷川

㱟磨・波毛康宏 (1995)：兵庫県南部地震に扔ける地

下水挙動調查結果、日本地下水学会1995年春季講演

会講演要旨、 $8 \sim 11$.

波毛康宏 (1986)：「淡路島の清水」. 秘教育出版セン 
夕一、147p.

波毛康宏・西村良司 (1994)：名水を尋ねて(27) 淡路島 の名水、地下水学会誌、Vol.36、No. 4、487 492. 兵庫県 (1995)：1：50,000表層地質図「須磨・明石・ 洲本小日本地図センター。
吉岡龍馬 (1988)：水質からみた風化現象、奥田節夫教 授退官記念事業会：「災害地形学最前線」京都大学防 災研究所、11 13.

(受付：1996年 8 月 4 日、受理：1996年 8 月30日) 